ODRODZENIE I REFORMACJA W POLSCE - SI 2017 - PL ISSN 0029-8514

Janusz Tazbir

\title{
From Antemurale to Przedmurze, the History of the Term
}

Even though the function of Poland as a bulwark in the history of modern Europe (and Christianity itself) has been frequently and eagerly discussed over the last several centuries, for a long time no researcher used it as the subject of a separate study. It was not until shortly before Poland regained independence that two popularising brochures were published, that is Fr. N. Cieszyński's Polska przedmurzem chrześcijaństwa (Poznań, 1916) and K. Konarski’s Polska jako przedmurze Europy wobec Wschodu (Warsaw, 1918). The two publications focused primarily on the battles fought by the Polish-Lithuanian Commonwealth against Muslims (Turkey and the Tatars) and did not discuss the origins of the term przedmurze ("bulwark") or its further history. It was not until fairly recently that it became the focus of academic works, published both in Poland (cf. J. Tazbir, "Przedmurze jako miejsce Polski w Europie," in: idem, Rzeczpospolita $i$ świat. Studia z dziejów kultury XVII wieku [Wrocław, 1971]) and in Italy or the USA. ${ }^{1}$ Two more studies - by H. Olszewski and U. Borkowska - have been published over the last several years. ${ }^{2}$

${ }^{1}$ Cf. S. Graciotti, "L'antemurale polacco in Italia tra Cinquecento e Seicento: il barocchizarsi di un mito," in: Barocco fra Italia e Polonia, ed. J. Ślaski (Warszawa, 1977); W. Weintraub, "Renaissance Poland and Antemurale Christianitatis," Harvard Ukrainian Studies 3/4 (1979-1980); P.W. Knoll, "Poland as antemurale christianitatis in the Late Middle Ages," The Catholic Historical Review 60, no. 3 (Oct.) (1974).

${ }^{2}$ H. Olszewski, "Ideologia Rzeczypospolitej przedmurza chrześcijaństwa," Czasopismo Prawno-Historyczne no. 2 (1983); U. Borkowska, "The ideology of "antemurale' in the sphere of Slavic culture (13th-17th centuries)," in: The Common 
The issue of antemurale is also discussed in my book Polskie przedmurze chrześcijańskiej Europy: mity a rzeczywistość historyczna, typeset for print in Wydawnictwo Interpress. Considering that the work is devoid of critical apparatus due to the current stage in the process of its publication, it does not exhaustively discuss the history of the term, or the formation of its Polish and Latin equivalents (propugnaculum fidei christianae, scutum, clypeus, murus, munimentum or praesidium). I would therefore like to discuss this issue in the present article.

What needs to be emphasised first is the fact that the word przedmurze (antemurale) had two independent meanings, either describing the defensive wall of a fortification or serving as a synonym for a fortress, stronghold, or rampart. The latter meaning seems almost destined to be used in reference to Poland, considering that the correspondence exchanged between Władysław the Elbow-high and Pope John XXII (1323) contains a description of the Kingdom of Galicia-Volhynia as a shield (scutum) against the dangerous Tatar hordes. Nonetheless, the letters exchanged between the last two Piast kings and Avignon do not contain even a single reference to bulwark. According to P.W. Knoll, the term ceased to be used in the aftermath of the Christianisation of Lithuania and a temporary halt in the Tatar attacks on Europe (which was connected to the disintegration of the Golden Horde). ${ }^{3}$ The popes no longer associated Poland with an entity defending Christianity against pagans; in turn, the country started to raise suspicions due to its attempts to turn the Holy See against a Catholic order. Such accusations appear in the desperate pleas for help sent out to European courts by the Teutonic Knights before the Battle of Grunwald. The letters sent by the order suggested that Jagiełło was trying to dismantle the entirety of Christianity. What other consequences could arise from the destruction of the Teutonic Order, whose state served as the eastern "shield and bulwark" of Christian Europe? When Władysław Jagiełło and Grand Duke of Lithuania Vytautas established diplomatic relations with the sultan after 1411, the Grand Master of the Teutonic Knights (Heinrich von Plauen) claimed that the two brothers were attempting to wage war against Christianity in alliance with "the enemies of the Cross". From that moment on, almost until the Battle of Varna, Poland was frequently accused of collaborating with

Christian Roots of the European Nations. An International Colloquium in the Vatican (Florence, 1982).

${ }^{3}$ Knoll, op. cit., pp. 387, 396. 
the Turks to the detriment of the Christian world; it was believed, for instance, that the Ottoman raid of Hungary in 1415 had been carried out with Polish consent.

Antemurale as an adjective was initially used to refer to the countries located at the frontline of the Turkish expansion, for example Malta and Crete, the Republic of Venice, which owned estates on the other side of the Adriatic Sea, or even the Republic of Ragusa. Before the fall of Constantinople, Byzantium had also been considered a bulwark state. In the aftermath of the Turkish conquest of the Balkans, the status of antemurale started to be assigned to the countries of Central and Eastern Europe, directly under threat of a Turkish or Tatar invasion. Since the second half of the fifteenth century, such vision of their respective countries was expressed by the rulers of Danubian Principalities. In his letter written in 1477 to the Senate of Venice, Stephen III of Moldavia describes the function of Wallachia and Moldavia as a "stronghold" and the guardian of Hungary and Poland, which would have already been seized by the Turkish power if not for the interventions of the Danubian Principalities. Several dozen years later (1542), the successor of Stephen to the Moldavian throne, Petru Rares, wrote a letter to Sigismund I the Old, in which he stated that Moldavia constituted the gate and key to Hungary and Poland, as well as "the threshold of all Christian lands". 4

These claims, however, fell on deaf ears in Rome; in the fifteenth century, the papal diplomacy considered Hungary to be the bulwark of Christianity and the main buffer in the struggle against infidels. It was only thanks to his accession to the throne that Władysław III of Poland started to be referred to as antemurale. The renown Italian humanist Francesco Filelfo thus addressed the young king before the Battle of Varna: "Ciebie świat zowie gwiazdą królów. Tyś jest przedmurzem całej rzeczypospolitej chrześcijańskiej”. ${ }^{5}$ Even though Hungary continued to be considered antemurale until the Battle of Mohács, ${ }^{6}$ the 1444 defeat nonetheless created a sui generis political

${ }^{4}$ J. Corfus, Documente privitoare la istoria Românei culese din arhivele polone secolul al XVI-lea (Bucureşti, 1979), p. 70; A.G. Savu, Stefan cel Mare, campanii (Bucureşti, 1982), p. 156.

5 S. Łempicki, Renesans $i$ humanizm $w$ Polsce. Materiaty do studiów (Warszawa, 1951), p. 11.

${ }^{6}$ It was not until 1526 that Klemens Janicki bemoaned the fate of Hungary, which once constituted "Poland's defensive wall against the Turkish peril", while Hieronim Powodowski concluded (1595) that even though Hungary was currently 
vacuum which was exploited - rather ingeniously - by the Polish diplomacy. Jagiełło's missionary merits, his son's heroic death in the battle against the Turks, Kazimierz Jagiellończyk's fight against the Tatars - all this allowed Poland to effectively defend itself against the aforementioned Teutonic propaganda. In 1450, Polish envoy to Rome Tomasz Strzempiński emphasised the achievements of his ruler, who had built a defensive wall "against the infidels" at the borders of his country. Four years later, the Pope (Nicholas V) was reminded of this feat by another diplomat - Jan Lutek. A similar tone was also adopted by Kazimierz Jagiellończyk himself in his 1456 letter to Callixtus III. ${ }^{7}$

When Archbishop of Crete Hieronymus Landus gave a speech in Cracow in 1462, encouraging the king to wage war against the Turks, he referred to Poland as the shield, wall, and bulwark (scutum, murus, antemurale) of Christianity, ${ }^{8}$ which should be interpreted not only as tactical flattery but also as an echo of the opinions planted in Rome by the representatives of the Polish diplomacy. Almost all of the envoys arriving to the Holy See emphasised, as did Jan Ostroróg in his speech delivered before Pius II (1467), that they had been sent by a monarch who, despite being surrounded by enemies, "did not allow for his kingdom or the entirety of Christianity to be attacked".? M. Biskup is therefore right to conclude that it was no other force but only the Polish diplomacy that "solidified the vision of Poland as the bulwark or 'shield' of Western Christianity in the Roman Curia and Western Europe". ${ }^{10}$

The Polish envoys were aware of the quick advancement of Turkish forces towards the borders of their country and thus presented the Turks as a threat not only to Poland but also to entire Europe. The term antemurale evoked specific associations connected to military constructions. It was therefore clear that the fall of the bulwark implied the advance of the enemy to the inner defensive wall, which would constitute a mortal danger to the fortress, that is to the

endangered by the Turks, it used to be "a strong wall protecting Christianity against them”. Cf. also Borkowska, op. cit., pp. 1210-1211.

7 Historia dyplomacji polskiej, vol. 1: Potowa Xw. - 1572, ed. M. Biskup (Warszawa, 1980), p. 474.

${ }^{8}$ J. Długosz, Historiae polonicae libri XII, vol. 5 (Cracoviae, 1878), p. 360.

9 Wybór mów staropolskich, ed. B. Nadolski (Wrocław, 1961; Biblioteka Narodowa, I, 175), p. 36.

${ }^{10}$ Cf. n. 6. 
community formed by the Christian European states. The Polish diplomacy believed that the continent needed to be constantly reminded of the country which keeps guard of its south-eastern frontier. This was the only effective way of gaining allies or at least obtaining some military enforcement or subsidies. Not only that - the diplomatic mission headed by Ostroróg also sought for Poland to be exempt from any payments to the Holy See due to its function as a bulwark. The envoy argued that it was only reasonable and just to lift any financial obligations from a country which protects not only itself but also Silesia, Moravia, Bohemia, and almost the entire territory of Germany "against the Turks, Tatars, and even against Muscovites or Valachs". It was crucial for the Polish monarch to keep the annates at his disposal, since his country, "situated at the edge of Christian Europe", lacked funds sufficient for the "protection of justice and keeping peace in the homeland". ${ }^{11}$ Sigismund I the Old used the same argument (the need to allocate funds for the defence against Turkey and Crimea) to excuse Poland's non-payment of Peter's Pence and annates (they eventually ceased to be paid in 1565). Rome's (very significant!) loss of revenue was therefore justified by the country's antemurale status. At the same time, it was emphasised that any support given to the Teutonic Order was detrimental to the Polish bulwark and, by extension, to the entirety of Christian Europe. "Oh, you Sarmatian kingdom, bulwark of Christianity, its barrier and protection from enemies", wrote Jost Ludwik Decjusz in 1521, bemoaning the fact that while Poland took upon itself the full impact of the "attacks of the worst enemies", there were many who "devised schemes" to destroy it and make it vulnerable to "the worst enemies of Christianity". ${ }^{12}$ This line of argument was later, consciously or not, employed by seventeenth-century diplomats. ${ }^{13}$

Poles were embittered by the insufficient compassion shown in Western Europe for their struggles against their eastern neighbour, especially since some of the European states openly supported Moscow.

${ }^{11}$ Filozofia i myśl spoteczna XIII-XV wieku, ed. J. Domański (Warszawa, 1978; 700 Lat Myśli Polskiej), p. 243.

12 J.L. Decjusz, Księga o czasach króla Zygmunta, ed. T. Bieńkowski (Warszawa, 1960), p. 121.

${ }^{13}$ In 1621, Jerzy Ossoliński spoke at the English court, stating that some European rulers were "worse than barbarians as they incite the evil enemy of Christianity [i.e. the Sublime Porte] to destroy others”; J. Ossoliński, Pamiętnik, ed. W. Czapliński (Warszawa, 1976), pp. 148, 160. 
Za nami jak za murem drudzy pokój mają,

A wżdy im to niewdzięczno, a naszem złem radzą

wrote Marcin Bielski, not missing the opportunity to present Poland as a bulwark. ${ }^{14}$ The Holy Roman Emperor, traditionally believed to be the lay guardian of Christianity, was most harshly criticised for failing to acknowledge the defensive function of Poland. Just as Venice, Austria, or Hungary felt deceived and disillusioned with the French support for the Sublime Porte, the Cracow court was indignant at the European treatment of Moscow, which was greatly favoured by the Habsburgs and seen as a future member of the Catholic community of nations by the Pope. This is why Poland was so insistent on constantly reminding other monarchs of the wars fought in the East for the benefit of the entire Christian community. The Polish assertion is reflected in the aforementioned opinions of the author of Memoriat, which must have been received with a large dose of scepticism, since even Callimachus saw it appropriate to contest the beliefs of those who presented the "public defence of all Christians" as Poland's private struggle to defend its boundaries. However, even if that was the case, argued Buonaccorsi, no one should expect "the one who wishes to help the other to not also have his own interest in mind". Rivers, the Sun, or the Moon are beneficial to everyone even though they follow the laws of nature. Analogically, "the extraordinary readiness of Poles to defend Christianity" provides protection for the entire Christian world. ${ }^{15}$ A similar conviction is reflected in numerous statements by Polish diplomats, writers, and rulers of the sixteenth century.

In January 1525, when reporting to Pope Leo X on the victorious Battle of Orsha, Sigismund I proudly emphasised that Poland was singlehandedly fighting not only against the Turks, Tatars, or "other Scythians from the other side of the Don" but also against the Grand Duke of Moscow, that Sarmatian-Asian tyrant, blasphemer and schismatic seeking to harm the "Roman Church". The Polish king pointed out that he did not wage these wars in the interest of himself or his country, but for the benefit of the entire "Christian community". ${ }^{16}$ Erazm Ciołek attempted to convince Emperor Maximilian of the same in 1518. When the very same year Pope Leo X presented a detailed

\footnotetext{
${ }^{14}$ M. Bielski, Satyry (Kraków, 1889; Biblioteka Pisarzów Polskich, 4), pp. 15-17.

${ }^{15}$ Kallimach, Ad Innocentium VIII de bello Tureis inferendo oratio (Warszawa, 1964), pp. 73-75.

16 Graciotti, op. cit., p. 307.
} 
plan for another anti-Turkish crusade (the so-called "holy union"), Sigismund I declared that he had long wished for such an expedition to be organised. However, he emphasised that he would only be able to join it after resolving the Polish conflicts with the Tatars, Moscow, and other enemies. Afterwards, if the crusade plans were to be implemented, the Polish king would gladly fulfil this duty alongside other Christian rulers. During the funeral of Sigismund I, Stanisław Orzechowski, probably the most popular political writer among the nobility, gave a speech in which he stated that all the wars fought by the monarch had meant to defend "the Christian religion against the Tatars and the Turks, and defend the honour of the Holy See against Moscow and Wallachia, its sworn enemies due to the conflict between the Greeks and Rome". The Polish king was the only one who fought "against the entirety of Asia not to expand his kingdom but to protect it, not on his own whim but in defence of the Christian faith". ${ }^{17}$ In 1569, Sigismund Augustus gave Queen Elizabeth of England the proposal to create an anti-Muscovite Alliance, invoking the common interest of Christian rulers and referring to Ivan the Terrible as "a barbaric and cruel opponent [- $]$ of all nations and peoples" and "the enemy of freedom in all its forms". If he were to receive a supply of weapons from the West, he would "come here, plunder, and - God help us destroy Christianity in a horrid calamity", wrote the last king of the Jagiellon dynasty. The battles fought against Moscow were described in similar terms by Krzysztof Warszewicki towards the end of the sixteenth century; he called the Muscovite ruler a tyrant and lauded the victories of Stephen Báthory as a triumph of civilisation and freedom over despotism and barbarism. ${ }^{18}$

Endre Angyal indicates that the constant state of conflict with the Muslim powers led to the creation of "a world of frontier fortresses", which in the sixteenth and the seventeenth century stretched from the Adriatic Sea to the Volga River. The inhabitants of this world, fighting "incessant battles against the perennial Turkish and Tatar enemy", developed a particular version of Baroque, encompassing numerous relics of the medieval knightly culture. In the countries which I would call the "world of the bulwark chain", one could still feel the presence

17 S. Orzechowski, Wybór pism, ed. J. Starnawski (Wrocław, 1972; Biblioteka Narodowa, I, 210), p. 70.

${ }^{18}$ R. Przeździecki, Diplomatic Ventures and Adventures. Some Experiences of British Envoyes at the Court of Poland (London, 1953), pp. 25-26; Graciotti, op. cit., p. 310 . 
of the "spirit of the crusades and the Reconquista in the times when it was already no more than a literary tool of Romanticism for most of the nations of Western and Northern Europe". Many of the verses written by Wacław Potocki, Samuel Twardowski, or Maciej Kazimierz Sarbiewski would fit perfectly into the works of South European, Hungarian, or even Bohemian poets singing the praises of the victorious battles against the Turks. The inhabitants of the "bulwark chain" were also convinced that it was God himself who gave the Hungarians (Poles or Croatians) this unique historical mission of eradicating the Turkish presence from the continent. ${ }^{19}$

At the turn of the sixteenth century, the humanist circles from almost entire Europe widely accepted the idea that Poland - alongside Hungary, Venice, or Spain - belonged to the Christian "world of frontier fortresses", defending the continent from Tatar hordes and Muscovite troops. Such an opinion was expressed in the correspondence written to Poles by Erasmus of Rotterdam and Philip Melanchthon, as well as in numerous works of German, French, or English (e.g., Ch. Marlowe) poets. However, it enjoyed much less popularity in Italy, not only but especially in Rome, where the Jagiellon dynasty was believed to actively evade any engagement in the anti-Turkish league. The papal officials did not consider the fight against Moscow or the Tatars to have enough significance for Poland to be labelled an antemurale state. As stated by Sante Graciotti, "Italy of the sixteenth century understood Poland's policy of neutralism but did not consider the country to be an anti-Turkish bulwark" ${ }^{20}$ One of the people who expressed strong scepticism in the matter, especially in view of the fact that the Polish-Ottoman relations were regulated by continuously renewed armistices and peace treaties, was Niccolò Machiavelli. His opinions stood in stark contrast to the erroneous but relatively popular legend, according to which he was the person who first referred to Poland as a bulwark; in fact, the author of The Prince wrote about the instances of "great Tatar raids successfully repulsed by Hungarians and Poles. These nations often gloat over their victories, claiming that Italy and the Church would have experienced the horrors brought by the Tatar hordes had it not been for their power". ${ }^{21}$ Towards the end of the sixteenth century, Italian political writer Paolo

\footnotetext{
${ }^{19}$ E. Angyal, Świat stowiańskiego baroku (Warszawa, 1972), p. 108.

${ }^{20}$ Graciotti, op. cit., p. 306.

${ }^{21}$ N. Machiavelli, Wybór pism (Warszawa, 1972), p. 412.
} 
Paruta described the future anti-Turkish coalition in his 1599 work Discorsi politici. He indicated France, Spain (and, naturally, Austria), Portugal, and Venice as the coalition members, but did not mention the Polish-Lithuanian Commonwealth. Europe needed a reliable military power that would be able to withstand the Ottoman attacks; in this respect, it preferred Moscow, with its strong centralised power, to a country where the whims of the nobility too often prevailed over the wishes of the monarch.

It is no coincidence that the only Italian humanist who indiscriminately considered Poland to be the "castle and bulwark of our religion" ("religionis nostrae arx et propugnaculum") was the aforementioned Callimachus, a servant to the Polish court. ${ }^{22} \mathrm{His}$ compatriots would only mention the defensive function of the Commonwealth during their visits to the country or in the letters sent to the members of the Jagiellon dynasty (e.g., Annibale Caro referred to Poland as "antemuraglia di christianità”). In 1573, Giovanni Francesco Commendone sought to convince the nobility to elect a Catholic ruler, explaining that only a king of such creed would be able to protect "this great kingdom, considered the bulwark of Christianity since time immemorial" from an invasion of pagans or heretics. ${ }^{23}$ Such belief was uncritically adopted by the Polish intellectual elite of the sixteenth century. The correspondence of Polish monarchs with Western European rulers, as well as the works of noble political writers and poets (e.g., M. Bielski and S. Orzechowski), reflect the vision of Poland as an effective buffer protecting the continent from Turkish, Tatar, and Muscovite raids. These writings would more and more frequently feature the word przedmurze ("bulwark"), as evidenced by the letter from Sigismund I to Albert of Prussia (1539), in which the Kingdom of Poland is described as propugnaculum and antemurale.

It would be necessary to devote at least a dozen pages or so just to list the titles of native and foreign works which, starting from the mid-fifteenth century, referred to Poland as the defensive wall, bulwark, fence, rampart, or shield of Christianity. For a long time, however, mostly the Latin equivalents of these terms were used, and the Polish terminology was developed relatively late. This also applied to the use of the Polish equivalent of antemurale, that is przedmurze. Antemurale

${ }^{22}$ Kallimach, op. cit., pp. 68-69.

${ }^{23}$ Zbiór pamiętników do dziejów polskich, ed. W.S. Broel-Plater, vol. 3 (Warszawa, 1858), p. 76. 
appears twice in the Old Testament, namely in Isaiah 26:1: "Ponitur in ea murus et antemurale" and in Lamentations 2:8: "Luxtique antemurale et murus partier". Until the end of the sixteenth century, both Catholics (Biblia Leopolity from 1561) and Christians of other denominations (the so-called Biblia Radziwittowska and Biblia Budnego from 1572) translated the term as parkan (pailing), baszta (fortified tower), przekop (ditch), or wat (rampart). It was not until the publication of the translation by Jakub Wujek (1599) that the familiar term przedmurze was used: "Będzie w nim położony mur i przedmurze" (Isaiah), "I płakało przedmurze i mur społem rozwalony jest" (Lamentations). ${ }^{24}$

The Bible uses antemurale in reference to Jerusalem. However, the dictionary by Grzegorz Knapski (1621), published around a dozen years after the Wujek translation, only lists the physical meaning of the term. The lexicographer describes przedmurze as "murek mały przed większym" ("a smaller wall in front of a larger wall”). The entry is cross-referenced to the terms: "podmurze, przymurze, zamurze, przedmurny, podmurny plac". ${ }^{25}$ When referring to the metaphorical function of the Commonwealth in Christian Europe, most authors still used the Latin term antemurale or such equivalents as "mur i szczyt chrześcijańskim państwom od nieprzyjaciół krzyża świętego” (Bishop Wawrzyniec Goślicki in the salutation of newly elected Sigismund III Vasa), ${ }^{26}$ "mur wiary prawdziwej" and "wał potężny od krajów pogańskich" (Sebastian Grochowski), or "płot" ("fence"), with which God "chrześcijaństwo od pogan zagrodził" (Wojciech Dembołęcki). ${ }^{27}$

Samuel Twardowski only uses the term przedmur in reference to the Polish-Turkish frontier. In Twardowski's narrative poem about Władysław Vasa, the prince sets out on an expedition against the Sublime Porte in 1621, wondering if he should confront the enemy in his own territory or rather

[- - ] stanąć obozem z tej tu od nas strony

I ten przedmur jakoby zaleć od Korony. ${ }^{28}$

${ }_{24}$ Biblia, to jest Księgi Starego i Nowego Testamentu (Kraków, 1599), pp. 772, 867.

${ }^{25}$ G. Knapski, Thesaurus polono-latino-graecus (Cracoviae, 1621), pp. 767, 873.

${ }^{26}$ A. Małecki, Wybór mów staropolskich swieckich, sejmowych i innych (Kraków, 1860), p. 110.

27 J. Tazbir, Rzeczpospolita i świat. Studia z dziejów kultury XVII wieku (Wrocław, 1971), pp. 66-67.

28 S. Twardowski, Wtadystaw IV, król polski i szwedzki (Leszno, 1949), p. 71. 
While Old Polish texts never referred to the Commonwealth as przedmurze, Latin works made very frequent use of the term antemurale. In 1620, Jerzy Ossoliński emphasised that Poland constituted "the safest bulwark of Christianity" ("validissimum christiani orbis antemurale") during his visit at the English court. ${ }^{29}$ A dozen or so years later, Jan Cynerski Rachtamowicz, a professor of the Cracow Academy, called the Commonwealth "the fortress of the true religion $[--]$, its most fierce defender and most devoted promoter, the bulwark of Christian states" ("antemurale Christianorum imperiorum") in his Latin pamphlet Pallas armata. ${ }^{30}$ In his polemic against John Barclay, known for his negative attitude towards Poland and Poles, Łukasz Opaliński wrote that it would be easy to "prove and conclude that we are a rampart or a barrier, or [- $]$ the bulwark of Christianity". ${ }^{31}$ A similar description of the Commonwealth can be found in Jakub Sobieski's book about the Battle of Khotyn; he then appeals to Christian monarchs for the support of "our kingdom, keeping guard of the Christian world as a shield and armour against pagans". ${ }^{32}$ His son (who went on to become King John III), too, called Poland the "bulwark and buckler of Christianity" in his speech on the emergence and development of the Turkish power, written during his studies at the Nowodworski Collegium. ${ }^{33}$ The meaning of the term was explicated by royal preacher Andrian Pikarski, who "gave a detailed speech on the concept of antemurale" during the 1672 Sejm meeting. He assigned the function of bulwark to the Polish Crown, whose knights were ready to defend its borders, and protect and spread the Catholic religion. However, when its citizens started to neglect their duties, God significantly decreased the size of the country. Here, the Jesuit preacher drew a parallel with the history of Jerusalem, which was punished by God in a similar way. The starting point of the sermon was a quote from the Bible, namely the aforementioned verse from Isaiah. ${ }^{34}$

It is important to note that the function of antemurale was assigned to either the entire Commonwealth or only the Kingdom of Poland,

${ }^{29}$ Ossoliński, op. cit., p. 118.

30 J. Cynerski Rachtanowicz, Pallas armata (Cracoviae, 1637), fol. $\mathrm{B}_{3}$.

31 Ł. Opaliński, Wybór pism (Wrocław, 1959; Biblioteka Narodowa, I, 172), p. 231.

32 J. Sobieski, Commentariorum Chotinensi belli libri tres (Dantisci, 1746), p. 17.

${ }^{33}$ H. Barycz, Lata szkolne Marka i Jana Sobieskich w Krakowie (Kraków, 1939), pp. 45-46.

34 Akta do dziejów króla Jana III, ed. F. Kluczycki (Kraków, 1883; Acta Historica, 6), pp. 1-2. 
but never to the Grand Duchy of Lithuania. This was probably due to the relatively recent introduction of Christianity to the territory of Lithuania and the fact that it did not directly take part in the struggle against Turkey, as well as due to the existence of only a single term to describe the Polish-Lithuanian state, both in the country and abroad. To put it in a nutshell, the term antemurale (or its Polish synonyms) was used rather generously, mostly in reference to the monarchs, their noble subjects, or to the only important fortress of the Commonwealth located on its southern frontier, that is to Kamieniec Podolski. As early as the beginning of the seventeenth century, Jan Jurkowski described King Sigismund III as being ordained by God to serve as

Strażnika i obrońcę wszech państw chrześcijańskich,

Tarczę i mur niezłomny od bestyj pogańskich. ${ }^{35}$

Overestimating his son's role in the victory of the Battle of Khotyn, the authors of numerous narrative poems (including Italians) hailed Władysław as "the bulwark of Christianity" since his early childhood.

A group of deputies to the 1632 Sejm presented a petition to ban religious orders from purchasing estates as in consequence "knights become poor instead of serving as the bulwark of Christianity" ("qui est antemurale christianitatis"). ${ }^{36}$ The noble levee en masse was also described, in quite excessive fashion, as "the rampart of Christianity, not once broken by the pagan onslaught". ${ }^{37}$ Wespazjan Kochowski used a rather clumsy Polish translation of the Latin term - antemurat - in reference to a Marian sanctuary (Studzianna) and to the very figure of Blessed Virgin Mary:

Tyś szyk wojska, szyk nieustraszony,

Tyś antemurał Polski niezwalczony.

O wieżo mocna, i w tej naszej stronie

Nowy Syjonie. ${ }^{38}$

Nonetheless, the location most frequently described with the adjective antemurale christianitatis, or its alternative Latin version: "totius christianitatis [- $[$ ] propugnaculum”, was Kamieniec Podolski. This

${ }^{35}$ J. Jurkowski, Utwory panegiryczne i satyryczne (Wrocław, 1968; Biblioteka Pisarzów Polskich, Ser. B, 13), p. 203.

36 A.S. Radziwiłt, Memoriale rerum gestarum in Polonia, 1632-1656, vol. 1: 16321633, ed. A. Przyboś, R. Żelewski (Wrocław, 1968), pp. 106-107.

37 Olszewski, op. cit.

38 W. Kochowski, Pisma, ed. K.J. Turkowski (Kraków, 1859), p. 98. 
is how it was referred to by the deputies to the Sejm and regional assemblies, who in 1746 called for the restoration of the stronghold, the "antemuralis of our Poland". ${ }^{39}$ In the trilingual dictionary by M.A. Trotz, published in 1764, Kamieniec is presented as the "gate to Poland" or the "bulwark of Christianity". ${ }^{40}$

We have, however, moved too much ahead. In the early seventeenth century the use of the term antemurale was, to say the least, controversial, both in Poland and in Italy. In poet Traiano Boccalini's drama piece depicting the struggle of European nations against the Sublime Porte, the Polish king (Sigismund III Vasa) confesses that "Poles lived in peace with the Turks" because they wanted to "let sleeping dogs lie" while treating the Austrian dynasty with significant reserve as it was "far from enamoured with the greatness of the Poles". ${ }^{41}$ Jan Botero, the author of an extensive description of the world, whose Polish translation was published in three editions $(1609,1613$, and 1659), wrote that the passive attitude of the Commonwealth towards the Ottoman Empire should be blamed on the Polish kings rather than the nobility, which "a wise and brave king is able to mobilise for any purpose". ${ }^{42}$ The opinion expressed by the Italian geographer merits our attention as, to some extent, it constitutes an echo of how the sixteenth-century position of the Polish "bulwark of Christianity" towards the Sublime Porte was perceived in Rome.

It would seem that at the time, the vision of Poland as a bulwark was promoted (and partially also worshipped) almost exclusively by the elites of the country (its political authorities, diplomatic service) and not by the majority of nobility, who were reluctant to provoke conflicts with the dangerous southern neighbour. One of the people who urged caution in the matter was Stanisław Sarnicki. In 1575, he wrote that it would be absurd to break the long-lasting peace, so carefully maintained by France; even Venice and the Holy Roman Empire did not decide to take any long-term military action against the Ottoman Empire. ${ }^{43}$ Twenty years later, the anonymous author of Deliberacyja

${ }^{39}$ Dyaryusze sejmowe z w. XVIII, ed. W. Konopczyński, vol. 11 (Kraków, 1912), p. 68.

${ }^{40}$ M.A. Trotz, Nowy dykcjonarz, to jest mownik polsko-francusko-niemiecki (Lipsk, 1764), col. 1656; idem, Nouveau dictionnaire françois, allemand et polonais (Leipzig, 1771), vol. 1, col. 779, vol. 2, col. 4768.

${ }^{41}$ Graciotti, op. cit., pp. 305-306.

42 J. Botero, Relatiae powszechne... (Kraków, 1613), Pt. 3, p. 175.

43 S. Sarnicki, De bello turcico deliberatio (Cracoviae, 1575), fol. $\mathrm{B}_{\mathrm{III}}$. 
o spotku i zwiazku Korony Polskiej z pany chrześcijanskimi przeciwko Turkom (1595) aimed to dissuade his compatriots from joining the coalition. He argued that the war waged by Europe would not be just because the sultan "has never offended or harmed us in any way". The Sublime Porte adhered to all treaties concluded with Poland and so should we. We will not avoid the "Turkish invasion" by joining the Christian league. The experiences of the past show us that we cannot rely on the support of other Christian countries.

There were numerous examples of anti-Turkish works in Old Polish literature, often penned by very prominent figures, generously funded with the papal, Habsburgian, or Venetian gold. Dissenting voices, such as the ones discussed above, were few and far between. Nonetheless, the nobility and its rulers were long reluctant to change the character of the Polish bulwark from defensive to offensive. One of the factors deterring the nobles from taking action was the support given to the potential anti-Turkish league since the second quarter of the fourteenth century by the Habsburg dynasty, cherished by a certain group of the magnates but despised by most of the members of the nobility. The expansion of the dynasty's influence, be it westward, southward (the territory of Italy), and in the area of Central and Eastern Europe, was anxiously observed by most of the noble population. Many believed the Habsburg tyranny to be just as horrid as the Turkish rule; their absolutist rule, based on the domination of the German spirit, was universally condemned. Another failure of the dynasty to seize the Polish throne, which took place in 1587, partially derived from the fear that it would drag Poland into a useless war against the Sublime Porte. Many believed that by taking over the Hungarian and Bohemian throne from the Jagiellon dynasty, the Habsburgs had willingly accepted the responsibility to resist the Turkish aggression on the south of Europe. In consequence, Poland would become the defensive wall rather than the bulwark proper, the function of which would be assumed by Austria. Moreover, for a long time the Polish nobility focused most of its attention on the northern enemy. The Turks, meanwhile, were only interested in seizing the areas located south of the Carpathian Mountains. The zone located in-between (the principalities of Wallachia and Moldavia) were controlled by a semi-peaceful condominium of both powers: the Ottoman Empire and Poland. In view of such a state of affairs, the "Sarmatian bulwark" was reluctant to wage a war against Turkey. This was evidenced by yet another prolongation of the peace treaty in May 
1619. Even though a mere year later the two powers faced each other in the historic Battle of Cecora, the noble society was not to blame for the conflict.

Moreover, it was not Cecora but the Battle of Khotyn (1621) which triggered the dramatic rise in the number of allusions to Poland as a bulwark, both in the Polish and foreign sources. The battle became a milestone in the history of antemurale, although the accounts of Rome officially granting Poland the title of the "bulwark of Christianity" should be taken with a pinch of salt. ${ }^{44}$ While Rome was generally not prone to officially confer such descriptors on Catholic countries, it certainly did widely publicise the battle. The letter from Urban VIII received by Władysław Vasa during his journey around Italy reads as follows: "Rzym wie, że ową pobudzoną z północnych i wschodnich kryjówek powódź Turków i Tatarów, która wydawała się tak niedawno grozić zalewem całej Europy, złamało męstwo polskiego Królewicza”. ${ }^{45}$ He was also presented with a prophecy, according to which he would once again defeat the Turks in 1633 and take the sultan himself captive. Italian authors of the time produced numerous lyrical and narrative lauding the Khotyn victory and "the Polish prince, the vanquisher of the East". The headquarters of this propaganda machine were located in Rome. The victory in the Battle of Khotyn was enthusiastically received by Pope Gregory XV, who (in his letters to nuncios) called "the Polish cause $[--]$ the European cause". The Pope described the Poles as "worthy of being granted the title of the liberators of the world and the vanquishers of the most menacing enemies by the entire Christian community". ${ }^{46}$

Alongside Lepanto, Khotyn became part of the liturgical calendar and was incorporated into the prayers read from the Breviary, an honour which had not been bestowed on the victorious battles of Grunwald or Vienna. ${ }^{47}$ From that moment on, Rome no longer doubted whether Poland really did constitute the antemurale christianitatis; this is how the country was referred to in one of the papal letters written in 1621. It was also emphasised by, among others, Pope Innocent XI,

${ }^{44}$ The issue was already discussed by $Ł$. Opaliński in 1648, cf. n. 31.

45 Podróż królewicza Wtadystawa Wazy do krajów Europy Zachodniej w latach 1624 1625 w świetle ówczesnych relacji, ed. A. Przyboś (Kraków, 1977), p. 274.

${ }^{46}$ Historia Kościota w Polsce, ed. B. Kumor, Z. Obertyński, vol. 1, Pt. 2 (Poznań, 1974), p. 215.

${ }^{47}$ Cf. B. Gładysz, Officium in gratiam Actione pro Victoria Chocimensi (Poznań, 1928), passim. 
who in 1678 , outraged at the conclusion of the Treaty of Zurawno, reprimanded the Polish Senate for ratifying the agreement because, as he argued, "the Kingdom of Poland has always been the mighty and distinguished bulwark of the Christian community". ${ }^{48}$

In the period of intense battles against the Turks, the number of statements defining Poland as antemurale was growing every year. This was thanks to the output of numerous poets and political commentators, authors of the lives of saints (especially the patrons of Poland, primarily Stanisław Kostka), and memoirists, parliamentary speakers, as well as diplomats serving at foreign courts. In Rome (1633), Jerzy Ossoliński emphasised that over many centuries Poland had defended Europe against the "savage and cruel enemies of Christianity". The Poles "stop with their bare chests $[--]$ the Ottoman crescents, [- -$]$ Muscovites, who are Christian in name only but whose very spirit and customs are far worse than the rest of the barbarians", and the Tatars, who would have already seized the entire continent had it not been for the Polish intervention. ${ }^{49}$

The choir of voices defining Poland as a bulwark was complemented by statements made by non-Catholic commentators. As early as 1597 , the author of the anonymous Calvinist pamphlet Oliwka pokój niosaca described Poland as "a bulwark of Christianity", standing in the way of the "greedy Turks". ${ }^{50}$ After the second battle at Khotyn, Arian émigré Zbigniew Morsztyn called his homeland "the barrier, rampart, and protection of all Europe". ${ }^{51}$ Such vision of the Commonwealth was almost universally accepted, as any dissidents would have to concede that Szymon Starowolski, their sworn enemy, was right in stating: "Ustawicznie walczymy z barbarzyńskimi narodami nie tylko w obronie własnych ognisk, ale i za cały świat chrześcijański". ${ }^{52}$ Such statements were often accompanied by the praises of the "holy war" which should be waged against the Turks. This is why Arian poet Olbrycht Karmanowski condemned those Christian soldiers

${ }^{48}$ K. Konarski, Polska przed odsiecza wiedeńska r. 1683 (Warszawa, 1914), p. 25.

${ }^{49}$ L. Kubala, Jerzy Ossolinski (Warszawa, 1924), p. 56. In the second half of the seventeenth century Poland was called "clypeus ac antemurale christianitatis" i.a., in: W. Kochowski, Annalium Poloniae... climacter primus (Cracoviae, 1683), pp. 1, 241.

${ }_{50}$ M. Korolko, Klejnot swobodnego sumienia. Polemika wokót konfederacji warszawskiej w latach 1573-1659 (Warszawa, 1974), p. 338.

51 Tazbir, Rzeczpospolita i świat, p. 66.

52 S. Starowolski, Polska albo opisanie Królestwa Polskiego (Kraków, 1976), pp. 57-58. 
[- - co tylko dla stroju

Krzyże noszą, a tymczasem nie myślą o boju;

Ani ich to obchodzi, choć Mahomet brzydki

Posiadł Górę Syjońską i Pańskie przybytki. ${ }^{53}$

Nota bene, Poland was most often called the bulwark of Christianity, with no Polish writers of the sixteenth or the seventeenth century referring to it as the bulwark of Europe. The sense of religious community was much more prevalent that the pan-European spirit.

It is worth noting that it was not until the seventeenth century that the mentions of Poland as antemurale ceased to be limited to "elite" sources and trickled down to materials produced for the masses by the politically involved nobility. At the time, however, even Polish-language works contained numerous Latin insertions. In mid-seventeenth century, Jan Karol Chodkiewicz and Jan Zamoyski were praised for "supporting the antemurale christianitatis" ${ }^{54}$ Before the fall of the Polish-Lithuanian Commonwealth, the country had not been described with the use of the Polish word przedmurze. The only known exception is the work Transakcyja wojny chocimskiej by Wacław Potocki (written ca. 1672, but printed as late as 1850), where the author writes that

$$
\begin{aligned}
& \text { [- - ] skoro się do Polski bisurmanin wrzepi } \\
& \text { I zniesie to przedmurze, bez wszelakiej chyby } \\
& \text { Będzie ich [chrześcijan] suchą ręką zbierał jako grzyby. }{ }^{55}
\end{aligned}
$$

Even though Trotz, already mentioned in this paper, explains the term "boulevard" as meaning "defence, bulwark, defensive wall of a country" and describes Poland as being a bulwark, but he does so in French.

In the eighteenth century, the weak and only semi-independent Commonwealth could no longer serve as anyone's stronghold, rampart, or defensive wall, which required significant military strength. All that was left of the former bulwark state, once essential to Europe's safety, was a complex of rickety fortifications. In early eighteenth century, Kamieniec Podolski, the former "antemurale christianitatis, not

53 J. Dürr-Durski, Arianie polscy w świetle wtasnej poezji. Zarys ideologii i wybór wierszy (Warszawa, 1948), p. 146.

${ }^{54}$ Rozmowy $w$ ciekawych i potrzebnych filozoficznych i politycznych materyjach, vol. 2 (Warszawa, 1761), p. 72.

55 W. Potocki, Transakcyja wojny chocimskiej (Kraków, 1924; Biblioteka Narodowa, I, 75), p. 48. 
attacked by anyone, would fall into ruin all by itself", wrote Władysław Konopczyński. ${ }^{56}$ "Wise government - that is your best bulwark", Poles were reminded by G.B. Mably in the Age of Enlightenment. ${ }^{57}$ For a long time, the noble society remained oblivious to these changes and still saw Poland as the mighty bulwark of Christianity, believing that God's Providence was watching over the country. Even in the period of the greatest Turkish threat, it was believed that God would not allow for the country where "there are so many good Catholics, so many churches and monasteries" to be defeated "by the pagan sabre". 58 This was how in 1709 Stanisław Szczuka explained that Poland would not be harmed in any way: "After all, the Sarmatia was called and proved to be the bulwark of Christianity". Therefore, if anyone was bold enough to attempt to destroy it, "the vandal, too, shall perish and experience his own downfall in another's demise". ${ }^{59}$

Political writers and historians, late Baroque preachers and authors continued to talk about the "respublica Christiana", defended by the sword and shield of the Polish antemurale. In reality, the defeat of Turkey in the Battle of Vienna (and Párkány) and the prevention of its further expansion constituted the final blow to the concept of the Christian community. The antithesis: Catholic (defender of the bulwark) - pagan (follower of Islam), was replaced by the opposition: civilised man (European) - barbarian (inhabitant of a different continent). In mid-eighteenth century, the king-philosopher in exile, Stanisław Leszczyński, wrote: "Czystą chimerą jedynie jest owa republika chrześcijańska, która miałaby uczynić sprawę wspólną ze wszystkich sprzecznych interesów narodowych" ${ }^{60}$

The same period also saw the ingression of Russia into the great family of civilised Europe. From that moment on, the Western European Enlightenment started to favour educated absolutism (including the rule of Catherine the Great) over the crumbling Commonwealth, often accused of anarchy and religious fanaticism. The West no longer saw it as Europe's protective shield against Moscow, especially since the latter was gaining more and more control over the Polish state. In the previous centuries, the Russian policy was limited to just one

56 W. Konopczyński, Polska a Turcja, 1683-1792 (Warszawa, 1936), p. 84.

57 G.B. Mably, Du gouvernement et des lois de la Pologne (London, 1781).

58 A.F. Grabski, Myśl historyczna polskiego oświecenia (Warszawa, 1976), pp. $18 \mathrm{f}$.

${ }^{59}$ Quoted after the Polish translation: S. Szczuka, Zaćmienie Polski swiatu powszechnemu wykazane (Kraków, 1902), p. 109.

${ }^{60}$ J. Feldman, Stanistaw Leszczyński (Warszawa, 1948), p. 215. 
part of the continent, and its conflicts with Sweden, the Crimean Khanate, the Sublime Porte, or Poland did not have any influence on Germany, France, or England. Having entered the group of the main European powers in the eighteenth century, the powerful Tsarist state gained influence over the decision-making processes in the continent. Consequently, the eastern border of Europe was moved by a thousand kilometres, making the Polish bulwark obsolete.

It would seem that if it had not been for the Polish loss of independence and the long period of its subjugation, the concept of antemurale would have become a thing of the past, and only the experts on the Polish-Turkish wars would ever describe Poland as a bulwark. Such an opinion was expressed by the herald of Polish positivism, Aleksander Świętochowski, who claimed that as long as Poland was a strong and independent country, it did not accredit to itself "the glory of a divine purpose" or perceive the mission fulfilled for the benefit of Europe as its raison d'être. However, when the country became weak, it started to consider itself the "defensive rampart" protecting Christianity from Islam and the Western civilisation from the "Eastern barbarism". After the loss of independence, Poles started to resort to fantasies, "to lull their minds and revel in the illusion of their divine purpose and resurrection for the redemption of the humankind", in a nutshell: to look for solace in the bulwark myth. ${ }^{61}$ The term, used in reference to the entire country and not only to its rulers or citizens (or a single fortress), only started to appear in its Polish version in writings produced during the period of the Duchy of Warsaw. Towards the end of the earlier century, Wincenty Skrzetuski used the term przedmurze to only describe Kamieniec, "which was once called the bulwark of Christianity". ${ }^{62}$ The quote was cited in the dictionary by S.B. Linde (s.v. "przedmur, przedmurze, przedmurek") and was the only reference to a bulwark in the entire publication.

Even though Stanisław Staszic (in his Przestrogi dla Polski) strongly criticised the concept of antemurale by stating: "Poganie są Rzeczypospolitej najwierniejszymi przyjaciółmi i obrońcami. To są chrześcijanie, którzy ją rozszarpali i którzy ją chcą zniszczyć" ${ }^{63}$ he did not once explicitly refer to bulwark. Around a dozen years later (1807), the same

${ }^{61}$ A. Świętochowski, "Polityka przedmurza," Prawda no. 4 (1881).

62 W. Skrzetuski, Prawo polityczne narodu polskiego, vol. 1 (Warszawa, 1782), p. 405.

63 S. Staszic, Przestrogi dla Polski (Kraków, 1926; Biblioteka Narodowa, I, 98), p. 139. 
author proudly concluded: "W Polsce jest przedmurze Europy przeciw nawałom z Azji". He saw his homeland as the country where people once "vanquished the hordes of Tatars, Turks, Cossacks, and Muscovites" ${ }^{64}$ The very same year, Jan Paweł Woronicz used one of his sermons to bemoan the ungratefulness of Europe, oblivious to the fact

[- - ] że Polska, jej mocne przedmurze,

Odpierała od reszty świata wschodnie burze. ${ }^{65}$

Andrzej Horodyski, a contemporary left-wing activist, wrote a letter to Józef Kalasanty Szaniawski, in which he described Poland as "the bulwark of Europe against the invasions from Asia". ${ }^{66}$

Considering that the vision of Poland as the bulwark of Christianity was not limited to the country itself, the term must have had its equivalents in other European languages. At first, it appeared in the translations of the two Bible verses cited before, both of which referred to Zion as antemurale. Later on, the concept started to be applied to the homeland of a given author. As early as the sixteenth century, the Holy Roman Empire (and Austria) started to be described as "das Bollwerk" or, less frequently, "die Vormauer des Christentums". Around the same time (or even earlier), there appeared the Spanish (baluardo) and Italian (antemuraglia and baluarte) equivalents of the term. In the seventeenth century, it entered French as boulevard. It was used to emphasise the function of France as a rampart against... England, where the term "bulwark" was adopted.

As in the case of Polish Kamieniec, the term started to be used in reference to strongholds or fortified towns. In the seventeenth century, Vienna became known as "das Bollwerk der Deutschen", while Racine described Cambray and Saint-Omer as "les deux plus forts boulevards" which the Spaniards owned in Flanders. On the other side of the continent, Evliya Çelebi, a Turkish explorer living in mid-seventeenth century, referred to the Ottoman fortress of Silistra (today's Bulgaria) situated at the Danube as "Seddiiman", which can

${ }^{64}$ S. Staszic, Pisma filozoficzne i spoteczne, vol. 3 (Warszawa, 1954; Biblioteka Klasyków Filozofii), pp. 221, 223.

65 J. Ujejski, Dzieje polskiego mesjanizmu do powstania listopadowego wtącznie (Lwów, 1931), p. 125.

${ }^{66}$ B. Grochulska, "Lewica wobec Napoleona w świetle 'Korespondencji w materiach obraz kraju i narodu rozjaśniających', in: Francja Polska XVIII-XIX w. Studia z dziejów kultury i polityki poświęcone profesorowi Andrzejowi Zahorskiemu (Warszawa, 1983), p. 67. 
be translated as the "bulwark of the [Muslim] faith". ${ }^{67}$ It is important to note that all these languages developed their native versions of antemurale much earlier that Poland (since the word antemurat was not used by anyone except Kochowski). They first started to appear in the sixteenth or seventeenth century, while the noble Commonwealth was first described as przedmurze after the country's dissolution.

Trans. by Natalia Ktopotek

First published as: "Od antemurale do przedmurza, dzieje terminu," Odrodzenie i Reformacja w Polsce 29 (1984), pp. 167-184

The publication of this English translation has received additional funding from the Ministry of Science and Higher Education of the Republic of Poland

${ }^{67}$ Księga podróży Ewlii Czelebiego (Wybór) (Warszawa, 1969), p. 387, n. 130. 